\title{
Some Facts About Constative And Performative Sentences, And Their Experimental-Phonetic Analysis (basing on French examples)
}

\author{
Mamedli Aysel Ali \\ Azerbaijan University Of Languages
}

\begin{abstract}
The article deals with the investigation of performative and constative sentences. The famous essay of J.Austin "How to do things with Words" has been investigated and analyzed widely. The meaning of the term 'speech act' has been exemplified in the article as well. The reasons of calling sentences performatives and constatives have also been analyzed in the article. According to J.Austin the name 'performative' is derived from 'perform, the usual verb with the noun 'action': it indicates that the issuing of the utterance is the performing of an action - it is not normally thought of as just saying something. The reason of calling some kinds of sentences 'constative' has been explained basing on the theories of J.Austin. The experimental-phonetic analyses of some performative and constative sentences have been carried out too. The results of the experiment have been shown in tables, and the calculations have been performed due to mathematical method.
\end{abstract}

Keywords: speech act, performative, constative, sentence, affirmative, descriptive, experiment, analyses

\section{INTRODUCTION}

The term speech act refers to what the speaker or writer is doing in pronouncing a special form of words. For instance, Come here! usually has the meaning of directing the listener to act in a certain way.

The proposition of a sentence is realized in speech acts. There are such kinds of sentences which are not used in affirmative. They are used only to give some information. For instance, Je te promets que je viendrai (I promise I will come.)

These kinds of sentences are called performative ones. The other kinds of sentences which are observed in speech acts are called constative sentences. The following sentence can be given as an example to illustrate a constative sentence Les enfants d'Ahmad sont méchants. (The children of Ahmad are all naughty).

The investigations show that the interest to performative and constative sentences took its beginning from the 1950-1960s years of XX century. Foreign linguists as well as native linguists have interset in this field. The performatives and constantives have been investigated by J.Austin, J.Searle in the English linguistics, N.D.Arutyunova, I.B.Shatunovsky, Q.Q.Poshepsova and others in the Russian linguistics, etc. The constative and performative sentences have been investigated in the works of F.Y.Veysalli. F.Y.Veysalli writes: Each part has its function in the sentence, and those parts have their special functions while connecting to the other parts. This case is possible to be observed in the speech acts of sentences. That is necessary while investigating performative and constative sentences as well" (Veysalli 2013, p.226-288). 
Investigating sentences it is observed that performative sentences are put in the opposite position to the performative sentences. It means that the meaning of a sentence becomes known when it is used. The previlige of this kind of usage is that it tries to solve some philosophical language problems in the people's acts, and in the level of speech acts. (Austin 1962, p.108).

The meaning of a sentence of a speaker depends on its reference with the the connection of the real environment.The speaker enters them speech acts for using understandable means for himself/herself. A sentence is used in speech act, but it is not acceptable if the reference or proposition is not true. The following example can illustrate our point of view:

Le Roi d'Iran est chauve. (The king of Iran is bald.)The reference is king in this example, but he doesn't exist really. It means that the sentence that is used in speech act cannot be identified in the proposition.

It is noteworthy to mention that the sentences of constative combinations was widely investigated by J.Austin. For explaining the meaning of sentences the theory of speech acts was investigated by him. J.Austin divided sentences into two parts from the constative and performative point of view. Approval, description can be given as examples for performatives, promise, warning, etc. can illustrate constantive ones. For instance,

Məsələn, performativ söyləmlər:

Excusez-moi (Je vous prie de m'excuser). (Excuse me.)

Soyez la bienvenue. (Bienvenue) (Welcome).

Je vous le recommand/conseille. (I advise it to you.)

These kinds of sentences can neither be true nor false. For their realization it is important to choose appropriate situation and conditions. Can I call the movement by this name? I do not have any legal permission for this. I am saying it for the purpose of conversation. Though I do not like the arrival of guests I have to say "Welcome!" These sentences can introduce performative ones. So, for differentiating performative sentences there should be three types of conditions: legitimacy, the sentences that are not used truely,and the destruction of conditions.

Using the performatives the sentence should begin with first person singular and the present tense may be used such as Je t'assure que/Je te promets que I promise (the passive voice can also be used).

Past tense is used only for descriptions. These kinds of sentences do not give any guarantee for realization of the action (Palmer 1976, p.161). The sentence such as Fermes la fenêtre (Close the window) is not considered to be an affirmative one. The word Bonjour (hello) is not used to introduce affirmative one, it is used only to express respect. The sentence such as Je serai là (I will be there) means that my being there is hypothesis, or it expresses my intention.

It is important to underline that sentences with performative constructions have grammatical structure. These sentences may express all semantic richness of the intention that the speaker sends.

The constatives that introduce the confirmation of facts can be meaningless as well. There are three case here: 
1. Ohmədin uşaqları hamısı keçəldir (Les enfants d'Ahmad sont chauves); Ohmədin uşaqları keçəl deyildir (Les enfants d'Ahmad ne sont pas chauves.) (halbuki Ohmədin heç uşağl yoxdur - Tandis qu'Ahmad n'a pas d'enfants);

2. Kimsə deyir ki, it həyətdə uzanıb (ola bilsin ki, o kimsə heç belə düşünmür) (Quelqu'un a dit que le chien dort dans le jardin) (Peut-être celui-ci ne pense pas comme ça.)

3. Mehmanxana sahibi deyir: qonaqların hamısı türklərdir. Sonra isə əlavə edir: Qonaqlardan bəzisi türk deyil. (Le directeur d'hôtel dit : tous les invités sont des turcs. Puis il ajoute : certains ne sont pas des turcs.)

The examples can introduce the opposition. The implicature, presupposition, and conclusion can also be observed in the given examples.

There is not any language fact that differs the constantives from the performatives. The communication means can be seen either in performatives (neither true nor false) or in constatives (proposition). The constative proposition is the realization of speech acts. Sometimes it is difficult to border them. For instance,

/Mən səni xəbərdar edirəm ki...// (Je t'averti que), /Mən təsdiqləyirəm ki...// (J'affirme que), there are either a little difference among these sentences, or not. They can introduce real facts. For instance, a doctor can say to his/her patient: /Mən sizə məsləhət görürəm// (Je vous conseille que) - using this sentence the doctor does not express the idea to be true or false, he only gives advice. The doctor may be true, but the result of his act is not clear enough. Of course, we can not be aware of the result of this speech act.

It is necessary to mention that J.Austin's great talent is seen in his ability for distinguishing the differences among words and their meanings. His famous essay "How To Do Things with Words" (Comment faire des Choses avec les Mots? ) can illustrate it. He (Austin) divided the types of adverbs into the following groups forming opposite among them (Austin 1962, p.60):

\begin{abstract}
"involuntorily" (qərəzliklə) (involontairement), "inadvertently" (ehtiyatsızlıqla) (par mégarde) , "by accsident" (təsadüfən) (accidentellement), "by mistake" (səhvən) (par erreur). Austin called this division "garden-variety statements", and states that they describe events and situations with expressing their descriptions. They govern the movement. For instance, the speaker using the performative verb "apologize" (üzr üstəmək) (s'excuser) and introduces the act of apology such as "I apologize for being late" (Gecikdiyim üçün üzr istəyirəm) (Excusez mon retard).
\end{abstract}

In his book "How to do things with words" (1962) he (J.Austin) writes that there are some utterances that do not report or 'constate' anything and are not therefore 'true or false, but rather that the uttering of the sentence is, or is part of, an action. For example, I name this ship Queen Elizabeth, I bet you sixpence it will rain tomorrow. If the speaker uses these sentences he/she (the speaker) really names the ship or makes the bet, but the speaker doesn not make any kind of sentence that can be considered to be true or false. These kinds of sentences that used by the speaker are grammatically correct, but they are not constative, they are performative. Austin distinguishes performative sentences as explicit performatives in contrast with the implicit performatives that do not cover an expression naming the act. For instance, Go as with I order you to go and There is a bull in the field may be considered as warning, but I shall be there may (or may not be a promise. These forms a distinction between locutionary act and an illocutionary act. The locutionary act means 'saying something', but the locution may be used for special purposes such as to answer a question, to announce a verdict, to give a warning, etc. In this sense an illocutionary act is performed. This process leads Austin 
and other scientists who have the same thought to use speech acts. Contrasting performatives and constatives, J.Austin claims that statements i.g. constatives are considered to be one kind of speech act. He writes: 'to perform an illocutionary act, say, to warn or to pronounce.' From the linguistic point of view the concepts of performative (i.g.I promise ...., etc.) and of speech act (i.g.There is a bull in the field as warning) are considered to be very different. Performatives are easily identifiable and they are formally marked; speech acts are not. F.R.Palmer suggests to distinguish a number of different kinds of linguistic phenomena which are related but are not quite the same (Palmer 1976, p. 165). For instance, I name this ship Queen Elithabeth has two clear characteristics. It is part of an action and it can christen a ship; then it starts with $I$ plus a present tense form, and it names the action while performing it. The similar example can be given like this I give and bequeath my watch to my brother. The utterances that can begin $I$ promise ...., I warn ...., I promise to come tomorrow, I warn you that there is a bull in the filed. These are performatives as they introduce promise, warning, etc. As it is seen the action is named by the verb (with both I and a present tense verb again). But these forms may differ from the first type of performative in that (1) they are not part of any conventional or ritual behaviour, and (2) the performative verb may be omitted without the loss of the illocutionary force; the naming of teh action does not seem to be an absolute requirement. It is possible to promise without using the verb to promise, but it is not possible to christen a ship without using the verb name. Warn can be compared with bet such as I bet you sixpence it will rain tomorrow. Palmer states that the bet is not 'on' unless the words I bet ... are used. I bet ... then is a performative in the earlier stricter sense, in that the performative verb is an essential element element and cannot be omitted. According to Palmer the expressions with the verb in the passive, but still clearly containing a performative verb. Austin's examples are You are hereby authorised to pay ...., Passengers are warned to cross the track by the bridge only, Notice is hereby given that trespassers will be prosecuted.

\section{METHODS}

J.Austin states that perlocutives effect the utterances illocutively. This act is performed by means of performative verbs. He suggests five classes of performatives which have illocutive force (Austin 1962, p. 34). They are the following:

1. Verdictives such as diagnose - diaqnoz təyin etmək; convict - ittiham etmək (condamner);

2. Exercitives such as appoint - müəyyən etmək (désigner, nommer);

3. Commisives such as vow - and içmək (prêter serment, jurer), oppose - qarşı çıxmaq (s'opposer à);

4. Behabitives such as apologize - üzr istəmək (s'excuser), curse - lənətləmək (maudire);

5. Expositives such as report - məruzə etmək (rapporter); argue - mübahisə etmək (se disputer).

J.Austin states that performatives have border. For instance, the same speech can be performative, or constative. That is why any speech act can be formed as performative, and illocutive power is not the exclusive load of performatives. For example, "San etmalisan X" (Tu dois faire) in this sentence "etmak" (faire) is not performative, but the special tone of a voice, or any other means of a verb can carry the load of illoctive power (Austin 1962, p.40).

\section{DISCUSSIONS ABOUT THE HISTORY OF EXPERIMENT}

The creation of scientific view took over 2 centuries to achieve moreover its foundation required the writing of scientific works in the evolution of this topic. Hence, A.von Hellwag's contribution can be considered as the first historical step ever made in the establishment of 
this discipline. Herein one may read observations on the articulation of vowels, while F.Y.Veyselli constituted a triangle of German vowels. A triangle which has not lost its value with the passing decades. A top of this his groundbreaking work shows visually the melodic structure of the language. In 1888 following the initiative of the French Academy of Sciences the Russian Empire Academy announced a competition to create an artificial language. As such, the Russian scholar Kratsenstayn won this competition with an apparatus that was able to pronounce individual taken sounds. After a while, W.von Kempelen from Vienna - repeating the work of Kratenstayn built another speaking apparatus. His machine however, could pronounce individually taken sounds as well words and small sentences. Since that time, any tendency to explore the features of sound-creation, by means of an instrument has only strengthened phonetics. What is more, this functional aspect of linguistics determined the future orientation of phonetics as a science of linguistics (Veyselli 2015, p. 176).

It is interesting to mention that the European scientists R.Rask, Y.Grimm and F.Bopp's enriched thoughts on linguistics by gradually aiding the foundation of a strong background for phonetic experimentation. On one hand, therefore, linguists like Y.Grimm proved unable to part company with "dead languages", whilst, on the other hand, physiologists, naturalists, psychologists etcetera, approached sound study from their own circle. Undoubtedly, they couldn't resist experiments on a linguistic table contents.

By 1876, in Germani, E.Sievers, is noteworthy after a year in England. Additionally, A.Sweet's books of phonetics make these two pathfinders significant in Europe. It is fascinating to read that E,Sievers acts as an opponent of experiment, even though his work is fundamental in defending personal observations by a writer. For their parts, O.A.Sweet, P.Passi, D.Jones, in Russia I.A. Baudouin de Courtenay, A.Thomon etcetra albeit not using the objective results gained through experiment, make observations considered as the most elegant illustrations of subjective method.

In Germany E.Sievers, J.Winteler, M.Trautmann, F.Techmer, O.Bremer and other famous scientists slowly matured. Certainly, F.Techmer was the first scientist to use a "science of phonetics" in the sense this phrase is applied now. Oddly enough, experimental phonetics did not develop either in England, or in Germany. Instead, it began to flourish in France - under the supervision of Monck J.J.Roussleau. Indeed, his legendary work-wherein he adapted methods employed by the natural sciences - directed the results of experiments to centre on language phenomenon.

J.J.Roussleau, along with L.Roudet, and side-by-side with M.Grammont, led their Germany disciples. Of J.J.Roussleau - G.Pancocelli-Calzia, M.Menzerath, later E.V.Skripchur and OI.von Essen. Meanwhile in Russia, V.A.Bogoroditsky and V.L.Sherba played great role in the development of experimental phonetics. In Europe, by the end of the XIX century and at the beginning of the XX century, I.A.Baudouin de Courtenay and F.de Saussure couldn't help spreading their positive influence over the realization of ideas in experimental linguistics.

Thusly, the development of phonetics (especially the emergence of experimental phonetics in the field of ideas), sought to find out which one - of so many valuable ideas - was not accurate. Really, looking back, it is impossible to show any filed of linguistics as energized as phonetics. Instructively, those sides getting into heated arguments over phonemes had to appeal to the methods of objective investigation as their Crown Court. Indeed, each was nourished by other sciences, especially philosophy, psychology, physics and so on - all of which undoubtedly influenced the development of phonetics. On the other hand, getting gradually away from "dead languages" as a litmus test of investigation, and learning the mechanisms of language as 
a means of intercourse, were the causes of experiment. Ordinary tape recording started this enterprise. Clearly, listening to a speech, and stopping it to relisten in any point, attracted the attention of the linguistics.

I.A.Baudouin de Courtenay's disciples B.A.Bogoroditsky and L.V.Sherba were the first ones to establish an experimental laboratory in Russia. Indeed, at the beginning of the century, L.V.Sherba carried out experiments in P/J.Rousselot's laboratory, afterwards returning to his native country to write his famous work "Quantitative and Qualitative Features of Russian Vowels" (1912). Different from other cities in Europe especially differing from Germany L.V.Sherba did not make experiments for the sake of experimentation, but rather made those investigations to scrutinize certain language phenomenon. For example, in his article "Quelques mot sur les phonemes consonnes composes" (1980), L.V.Sherba pointed out that the length of sound combination - not being longer than the length of other phonemes in language had the same sound combination, and could be considered as one phoneme (Sherba 1974, p. 36).

At the end of the XIX century, in Europe, some journals and collections were published. In France "Maitre de phonetique", in Holland "Archives Neerlandises de Phonetique experimentalle" can be considered examples to this. Furthermore, in this period the International Phonetics Society began its activities.

As a result of the intensive labour of this society, in the field of learning phonetic structure, a number of suggestions were made to advance research eventually being approved. So, tables were worked out through transcription signs, reflecting vowels and consonants in the languages of the world. All of which can be seen as an instance of projects fulfilled by the International Phonetic Association. Beginning moreover, in the XX century the circle of interest widened to involve issues surrounding the practical learning of languages. O.Jespersen from Danmark and L.Hjelmslev, from Germany W.Vietor as well as T.Siebs and from Russia V.Bogorodistsky alongside the theoretical issues of phonetics kept practical topics in their focus of attention. What is more, in the 2o's of the XX century "TCLP" created, in Prague city, a way to learn such systems synchronically. So, they accepted as a dominant orientation. Now , the $9^{\text {th }}$ volume of the collection published by this society consists of N.S.Trubetzkoy and his supporters when considering phonetics especially experimental phonetics were largely correct (Trubetskoy 1960, p. 78). By contrast, E.Zwirner was busy working out theoretical principles of his own, in order to develop phonometrics in Germany (Zwirner E. und Zwirner K. 1936, p.36). Overall, he thought it possible to determine the coefficient of sound variations by statistical methods and in this way find mathematical solutions to speech norms. He acted, therefore, from real existence, making observations, writing notes (by means of apparatuses), and measured speech events so as to find a medium mark for sound classes along with sound norms. Through this, he aimed to determine the marks of variation zones therein related.

\section{EXPERIMENT}

Let's analyse a sentence in French: /À la tête d'un orchestre sur-volté/, Hans Zender réussit là/quelque chose de proprement//

According to the acoustic parameters of the sentence, the intonation contour of the sentence has been defined. The determined acoustic parameters has been written in the table, and basing on them the obtained acoustic parameters has been written in the graphic. 


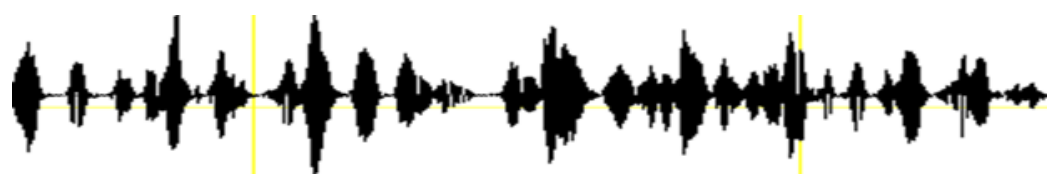

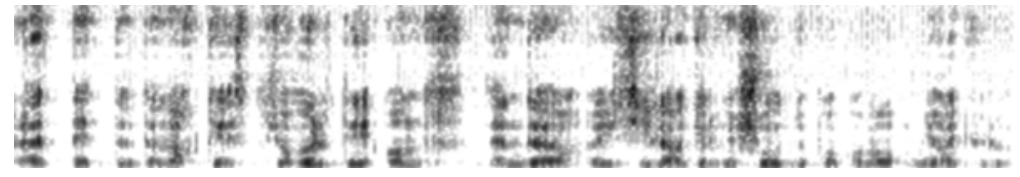

/À la tête d'un orchestre sur-volté/, Hans Zender réussit là/quelque chose de proprement//

Table 1

\begin{tabular}{|l|l|l|l|l|l|l|l|l|l|}
\hline $\begin{array}{c}\text { vowels } \\
\text { parameters }\end{array}$ & Al & $\Lambda$ & ə) & ə & u: & 9 & 9 & 7 & $\partial$ \\
\hline $\mathrm{f}(\mathrm{hs})$ & 145 & 190 & 130 & 126 & 140 & 136 & 130 & 143 & 112 \\
\hline $\mathrm{i}(\mathrm{db})$ & 74 & 75 & 72 & 70 & 71 & 60 & 63 & 69 & 59 \\
\hline $\mathrm{t}(\mathrm{m} / \mathrm{san})$ & 124 & 110 & 84 & 80 & 90 & 290 & 60 & 96 & 95 \\
\hline
\end{tabular}

The intonation contour and the frequency parameters of the main tone prove that the complete intonation has been realized. In /À la tête d'un orchestre sur-volté/, Hans Zender réussit là/quelque chose de proprement//

The middle tone frequency of the vowels is observed in $139 \mathrm{hs,} \mathrm{though} \mathrm{the} \mathrm{parameters} \mathrm{of} \mathrm{the}$ main tone frequency is lower than the parameters of the middle tone frequency. For example, at the end of the sentence the vowel / 7 / has the main frequency of $110 \mathrm{hs}$. The interval difference is in $29 \mathrm{hs}$ quantity in the sentence. Though the melodic parameter of the vowel is in $145-190 \mathrm{hs}$ quantity, and it is higher than middle tone register. The melodic pitch in the sentence in the second sillable is $190 \mathrm{hs}$ and it is necessary to state that this indication is possible for an intonation contour of a declarative sentence (See table 1, gr. 1). The analysis of the time parameter shows its differentness from the parameters of the melodicy. The middle pronunciation temp basing on the absolute parameters is $113 \mathrm{~ms}$. The pronunciation temp is getting to be lowered in the length parameters of the sentence. At the end syllable of the sentence the lengh of the vowel $/ 7: /$ is $95 \mathrm{~ms}$. The time parameters are increasing nearly at the end of the sentence, and these are the signs for an intonation of completeness. The parameters of the intensivity of the sentence show its weakining direction. The middle intensivity is $68 \mathrm{db}$. The amplitude parameters at the beginning of the sentence are $74-75 \mathrm{db}$, 59ds is observed at the last syllable. The interval difference in intensivity parameters is $59 \mathrm{db}$. (See: table. 1, gr. 1).

Basing on the results of the ossillographic analysis prove that in the analysed sentence the intonation of completeness has been observed.

\section{CONCLUSION}

It is known that it is impossible to investigate the language without carrying out experiment. That is why, from a phonetic view point, speech sounds, or different language units can be examined using the scopes of the experiment. The results of a well-carried out experiment is always reliable. In Azerbaijani the experimental-phonetic analysis of language facts are supported by linguists day by day. Most universities in Azerbaijan have experimental-phonetic laboratories which help the investigators to carry out their experiments using exact calculation numbers. 
Ali, M. A. (2017). Some Facts About Constative And Performative Sentences, And Their Experimental-Phonetic Analysis (basing on French examples). Advances in Social Sciences Research Journal, 4(11) 23-30.

\section{References}

Austin J.L. How to Do Things with Words. Oxford: oxford University Press, 1926.

Veysalli F.Y. The bases of Linguistics. Baku, Muterjum, 2013.

Lyons J. Linguistic Semantics: An Introduction. Cambridge: Cambridge University Press, 1995.

Palmer F.R. Semantics. Cambridge: Cambridge University Press, 1976.

Sherba L.B. The system of a language and speech acts. Moscow: Education, 1974.

Trubetskoy N.S. The basic of phonetics. Moscow: Moscow Publishing House, 1960.

Veysalli F.Y. Phonetics and phonological problems. London: Cambridge University Press, 2015.

Zwirner E. and Zwirner K. Basic questions of phonemes. Berlin, 1936. 